\title{
Socio-Economic Status and Living Conditions of Coastal Communities: Impacts on the Mangrove Ecosystems in the Scarcies Estuaries, Sierra Leone, West Africa
}

\author{
Komba Jossie Konoyima ${ }^{1, a^{*}}$, Raymond Geoffrey Johnson ${ }^{1, b}$
}

${ }^{1}$ Institute of Marine Biology and Oceanography, University of Sierra Leone, Freetown, Sierra Leone

a*konoyimak@gmail.com, btraymond12001@yahoo.com

Keywords: Mangrove Ecosystem, livelihood, vulnerable, coastline, Scarcies Estuary

\begin{abstract}
This research was conducted between the periods of March 2015 to December 2015 in the Scarcies Estuary, Sierra Leone. Participatory methods such as Focused Group Discussion (FGD), Interviews and ranking exercises were used for the assessment. The objective of this study is to assess the social and economic constraints of coastal communities, and how such constraints have influenced mangrove loss in the area. Knowledge on those is scarce for this region. The study will contribute to improving sustainable management agenda for mangrove forests in the Scarcies Estuaries. Results show a more active and productive age range of respondents (31-40 years), capable enough to make decisions that could influence resource use. A Student's t-test showed no significant difference in sex at $(\mathrm{P}>0.05)$ for male $(70 \%)$ and female $(30 \%)$ mangrove dependents. In addition, of the various mangroves related economic activities, oyster collection and farming remained the most important with income above One Million Leones ( $>115$ USD) per week and per farming season respectively. Further, key constraints in the communities included inadequate health centers, educational facilities and lack of basic material assets. Multiple households in a dwelling unit are also a common residential arrangement in these areas. Such living conditions are in the context of the definition of poverty with such outcomes as deprived resources such as money and assets, poor health and illiteracy. Hence, it is increasingly evident that the conservation of mangroves in this region cannot be done without considering the varying impacts of poverty, gender roles and resource utilisation patterns.
\end{abstract}

\section{Introduction}

Mangroves live at the interface between land and sea in tropical and subtropical latitudes [14]. However, mangroves are dependent on the coast, for which humans also have a preference [5]. Nearly 120 million people will live within $10 \mathrm{~km}$ of the remaining large mangrove habitats by 2015 [5]. This ecosystem is key for enormous abiotic and biological resources and offers a mixture of ecosystem services from which humanity benefits [6-8]. These services can be categorized into provisioning, supporting and regulating, and cultural [9-10]. Provisioning services include (i) fisheries production [11-15]; (ii) production of timber and wood [1, 16]; (iii) Medicinal purposes [17]. Supporting and regulating services include (i) carbon sequestration [2, 18, 19]; (ii) climate regulation [5, 20-22]; (iii) shoreline stabilization and coastal protection [23-25]; (iv) water filtration [26] and pollution regulation [27-29]; Mangroves also provide a suite of cultural and aesthetic services, which include: (i) recreation and tourism [30]; (ii) educational opportunities [5, 31, 32]; (iii) aesthetic and cultural values [32-33]. Cumulatively, the ecosystem services contribute to the socioeconomic wellbeing of coastal communities [5, 34, 35]. [36] had also shown that the majority of people living in mangrove areas globally are fishermen, deriving their livelihood from fishing and related activities. In addition, [5] argued that the way mangroves are valued by people around the world differ greatly and are influenced by culture, heritage and the level of dependence on mangroves for local livelihoods and well-being.

Notwithstanding, despite widespread knowledge of their value, the distribution of mangroves has decreased globally. Some 2,260 nationally designated and 285 internationally recognized sites worldwide contain about $41 \%$ of the world's remaining mangroves [5]. One-third of global mangroves have been lost over a 50-year period due to anthropogenic activities [37]. Studies have 
shown that mangroves have global coverage of between 10 and 24 million hectares, covering about $1 \%$ of the terrestrial surface of the earth [3]. The conflict between human needs and preferences and the conditions favored by mangroves is the fundamental driver for the loss and degradation of these ecosystems [38], and this decline continues in many regions [2, 39, 40-45]. The main threats are (i) Conversion to agriculture or aquaculture $[5,36,43,46-51]$; (ii) Coastal development $[5,40,46,52-$ 54]; (iii) Pollution, hydrological changes and indirect disturbance [44, 53, 55-58]; (iv) Exploitation [48, 59]; (v) Climate change and extreme weather events [20, 21, 60]. In Africa, the main hot spots of mangrove loss are in Mozambique and Western Africa through conversion to agriculture/aquaculture [48]. The rate of loss may be as high as 8 per cent per year in some developing countries [39]. Further, the majority of West African countries are among the least developed countries whose populations have a characteristically high dependency on natural resources [38]. Consequently, continuous degradation and deforestation as a result of uncontrolled exploitation and land conversion is taking place on a large scale $[5,47,48,58,61,62]$.

In Sierra Leone, the mangrove swamps are dominated by six (6) species, Rhizophora racemosa, Rhizophora. mangle, Rhizophora. harrisonii, Laguncularia racemosa, Avicennia africana and Conocarpus erectus [64-66]. About eighty percent of the population in Sierra Leone is rural and depend heavily on biodiversity resources for their food, fibre, medicine, income and wellbeing [66]. The ecosystem serves as home for many fish and shellfish [67-68], which then serve as source of protein for many people $[64,69]$. There has been a decrease in mangrove area coverage in Sierra Leone from 183,789 hectares in 1987 [70] to 90,790 hectares in 2015 [71]. In the Scarcies Estuaries where the highest threats on mangroves in Sierra Leone have been recorded by other authors, decline is from 7.1\% [70] to 6.3\% [71]. Key drivers of mangrove loss include conversion for rice field and salt production, overexploitation and logging for wood and timber [64-66, 69, 71]. There is scanty literature available on the linkage between the social and economic conditions of coastal communities and mangrove resource utilization in the Scarcies Estuaries. Most works have focused mainly on the ecology [67, 68, 70, 72] and services of the Mangrove Ecosystems [64, 69, 70, 73-75]. This research aimed at investigating some aspects of the social and economic constraints of coastal communities, and how those have influenced the loss of mangroves in the Scarcies Estuaries. The results of this study will contribute to improving sustainable management agenda for mangrove forests in the area by providing information on key issues responsible for the unsustainable uses and conversions of mangrove resources in the area.

\section{Theory}

Mangroves are widely recognized as being one of the most important and valuable of coastal ecosystems. On a local scale they are known to provide coastal protection, fulfill important functions in terms of providing nursery grounds and breeding sites for fish, birds, mammals, crustaceans, reptiles, and shellfish and are a renewable source of wood and food for many indigenous settlements $[1,8,10,19,76]$. Globally, they form part of the most important ecosystems in mitigating climate change given their considerable capacity to sequester carbon [76, 77]. However, in the past few decades, mangroves in Sierra Leone have been subject to a wide variety of threats. There has been an estimated decline of 183,789 hectares in 1987 [70] to 90,790 hectares in 2015 [71]. Greatest declined has occurred in the Scarcies Estuaries, from 7.1\% [70] to 6.3\% [71]. In many coastal areas of the Sierra Leone coast, the threats are mainly anthropogenic $[66,69,78$,$] . It has been postulated that the$ conflict between human needs and preferences and the conditions favored by mangroves is the fundamental driver for the loss and degradation of these ecosystems [38], and this decline continues in many regions $[2,39,40-45]$. In addition, there has been scientific consensus that human-induced disturbances may permanently alter the ecological functioning of mangrove forests [16, 79-81]. This might affect its capacity to sustain the provision of benefits to humans [16]. A strategy to improve the Mangrove Ecosystem management agenda would be to investigate the key drivers of mangrove loss in the study areas, which form the basis of this study. 


\section{Methodology}

\section{Study Area}

The specific study areas in the Scarcies Estuary are located in the Kambia District, Northern Province of Sierra Leone situated on $9^{\circ} 10^{\prime} \mathrm{N} 12^{\circ} 45^{\prime} \mathrm{W}$. The district is the main rice bowl of the country and the population is mainly farmers compared to fishing [82]. The hydrology of the district mainly constitutes the Scarcies Estuary, the Great and Little Scarcies, which merge towards their mouth before emptying into the Atlantic Ocean [67, 83]. Of the two rivers, the Great Scarcies contain most of the mangrove vegetation in this area [84]. Bordering the Great Scarcies Estuary include coastal villages of the study areas such as Rokupr, Mambolo, Kychom, Kassiri and Yeliboya (Fig. 1).

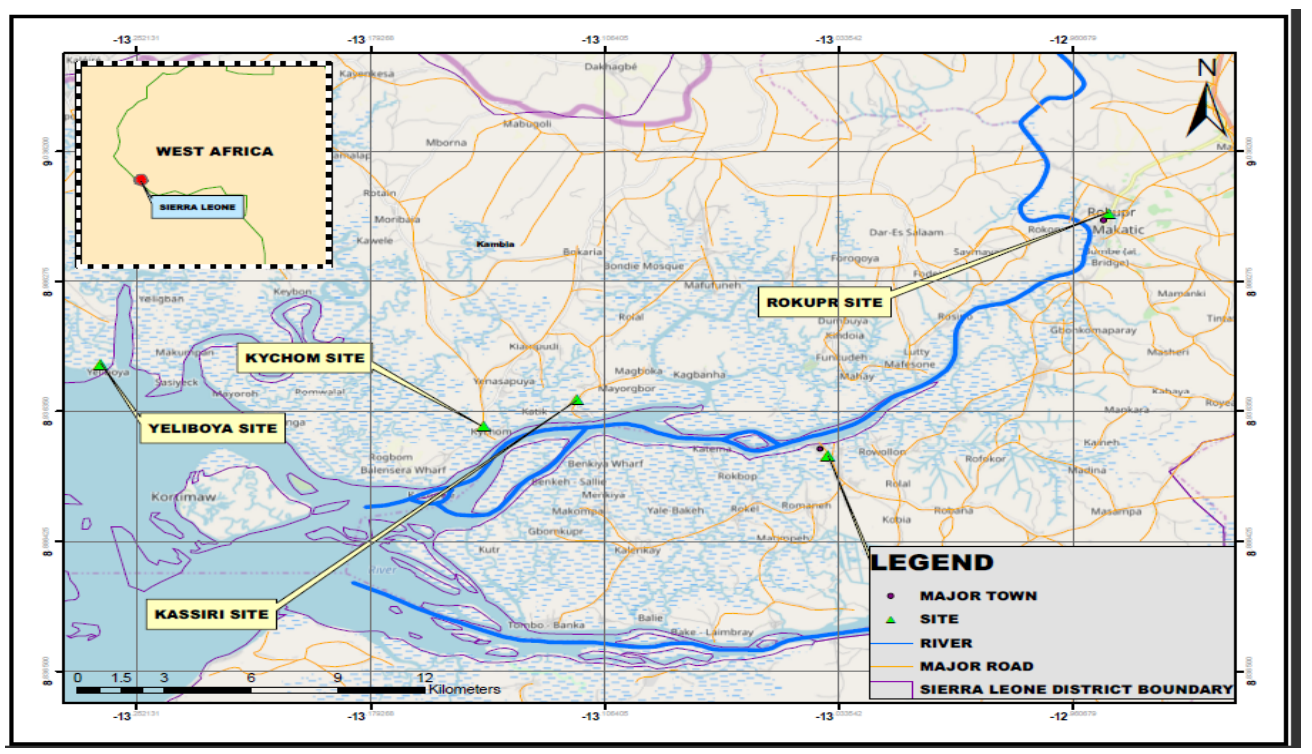

Figure 1. Map showing study locations in the Great Scarcies Estuary

\section{Sampling and Sampling Frequency}

This study was undertaken between the periods of March 2015 to December 2015 in five (5) coastal settlements in the Scarcies Estuary, including Rokupr, Mambolo, Kychom, Kassiri and Yeliboya. As a strategy, each community was divided into 5 strata from a reference point (popular point such as mosque) and eight participants were selected at random from each stratum for interviews and discussions, giving a total of 40 respondents for each settlement altogether. Care was, however, taken to have a representation of those individuals directly involved in mangrove-related activities. This is to ensure that members of the group had something in common which is important to the investigation. Further, Focus Group Discussions (FGD) and interviews comprise the participatory methods used to solicit information from participants. Ranking exercises provided information on income and emphasized the importance of the various mangrove-related economic activities in the area. The advantage of using the methods is that these allow wider participation of the local people. These methods had also been seen to be very effective by other researchers in increasing the potential of obtaining useful information particularly in remote areas [85-92].

Statistical analysis using the Student's t-test for significance in sex of participants was completed using the Microsoft Excel (ver., 2010) computer analysis package.

\section{Results}

\section{Age and Gender}

Data for this study shows that an average proportion $(51.5 \%)$ of the sampled respondents generally fell within a more active and productive age range of 31-40 years (Table 1). 
Table 1. Age of participants

\begin{tabular}{|c|c|c|c|c|}
\hline Age Group & $\mathbf{2 0 - 3 0}$ & $\mathbf{3 1 - 4 0}$ & $\mathbf{4 1 - 5 0}$ & $\mathbf{5 1 - 6 0}$ \\
\hline Rokupr & 7 & 10 & 2 & 1 \\
\hline Mambolo & 8 & 11 & 0.5 & 0.5 \\
\hline Kychom & 5 & 13 & 1.5 & 0.5 \\
\hline Kassiri & 8.5 & 10 & 1 & 0.5 \\
\hline Yeliboya & 10 & 7.5 & 1.5 & 1 \\
\hline Total (\%) & 38.5 & 51.5 & 6.5 & 3.5 \\
\hline
\end{tabular}

Generally, eighty-six per cent $(86 \%)$ of the respondents are engaged in economic activities linked to the Mangrove Ecosystems. A Student's t-test (df. 4; probability, $\mathrm{P}=0.124 ; \alpha=0.05$; twotailed) however shows that there is no significant difference in sex at $(\mathrm{P}>0.05)$ for male $(70 \%)$ and female (30\%) mangrove dependents of female to male sex ratio, 1:2.3 (Table 2).

Table 2. Mangrove economic activities

\begin{tabular}{|c|c|c|c|c|c|c|}
\hline Sex & Farming & Fishing & $\begin{array}{c}\text { Sales of } \\
\text { mangrove } \\
\text { products }\end{array}$ & $\begin{array}{c}\text { Other occupations } \\
\text { related to mangrove }\end{array}$ & $\begin{array}{c}\text { Other } \\
\text { commerce }\end{array}$ & Total \\
\hline Male & 54 & 39 & 17 & 11 & 20 & 141 \\
\hline Female & 23 & 16 & 7 & 4 & 9 & 59 \\
\hline Total & 77 & 55 & 24 & 15 & 29 & 200 \\
\hline
\end{tabular}

From Table 2, 'Sale of mangrove products' referred to those individuals engaged in the sale of charcoal, oyster, mangrove wood, etc. while 'other occupations related to mangrove' constituted activities such as boat building; handicraft-basket, needle for weaving fishing nets. Other commerce accounted for the variety of other trades not related to the Mangrove Ecosystems.

\section{Living Conditions}

Table 3 provides an inventory of health facilities in the study areas. The figures in brackets indicate the number of items presents. Government hospitals are only found in Rokupr, Kychom and Kassiri. There is no health facility in Yeliboya, and only one health centre in Mambolo manned by community health officials.

Table 3. Inventory of Health Facilities

\begin{tabular}{|c|c|c|c|}
\hline Letter name & $\begin{array}{c}\text { Community Health } \\
\text { Center }\end{array}$ & $\begin{array}{c}\text { Government } \\
\text { Hospital }\end{array}$ & $\begin{array}{c}\text { Private } \\
\text { Hospital }\end{array}$ \\
\hline Rokupr & Yes (1) & Yes (1) & No \\
\hline Mambolo & Yes (2) & No & No \\
\hline Kychom & No & Yes(1) & No \\
\hline Kassiri & No & Yes (1) & No \\
\hline Yeliboya & No & No & No \\
\hline
\end{tabular}

* "Yes" means, "it is present" and "No" means, "it is not present".

Further, from Table 4, Arabic education is the dominant system of education (46\%) in the study areas as compared to western education, which included primary, secondary and tertiary educational systems. 
Table 4. Educational status of respondents

\begin{tabular}{|c|c|c|c|c|c|}
\hline Status & Rokupr & Mambolo & Kychom & Kassiri & Yeliboya \\
\hline & $\begin{array}{c}\text { Frequency } \\
(\%)\end{array}$ & $\begin{array}{c}\text { Frequency } \\
\mathbf{( \% )}\end{array}$ & $\begin{array}{c}\text { Frequency } \\
\mathbf{( \% )}\end{array}$ & $\begin{array}{c}\text { Frequency } \\
\mathbf{( \% )}\end{array}$ & $\begin{array}{c}\text { Frequency } \\
\mathbf{( \% )}\end{array}$ \\
\hline $\begin{array}{c}\text { Did not go to } \\
\text { school (Illiterate) }\end{array}$ & $15(7.5)$ & $10(5)$ & $8(4)$ & $16(8)$ & $13(6.5)$ \\
\hline $\begin{array}{c}\text { Complete primary } \\
\text { school }\end{array}$ & $4(2)$ & $6(3)$ & $7(3.5)$ & $5(2.5)$ & $6(3)$ \\
\hline $\begin{array}{c}\text { Complete } \\
\text { secondary School }\end{array}$ & $2(1)$ & $3(2)$ & $2(1)$ & $3(1.5)$ & $3(1.5)$ \\
\hline Vocation & $1(0.5)$ & $1(1)$ & $0(0)$ & $2(1)$ & $0(0)$ \\
\hline Arabic education & $18(9)$ & $20(10)$ & $22(11)$ & $14(7)$ & $18(9)$ \\
\hline Tertiary education & $0(0)$ & $0(0)$ & $1(0.5)$ & $0(0)$ & $0(0)$ \\
\hline
\end{tabular}

$* \%=$ percentage frequency.

Similarly, Table 5 gives an inventory of educational institutions in the study areas. The figures in bracket show the number of items present. From Table 5, Yeliboya is in the worst case of educational facilities with only one primary school and no secondary school or vocational institution. There is also no vocational institution in Kassiri and Mambolo. Rokupr and Kychom are much better in terms of educational institutions. Interestingly, respondents from Rokupr are amongst the highest record of illiteracy rate during this survey.

Table 5. Inventory of educational institution

\begin{tabular}{|c|c|c|c|c|c|c|}
\hline Institution & Rokupr & Mambolo & Kychom & Kassiri & Yeliboya & Total \\
\hline & & & & & & \\
\hline Pre-school & Yes (3) & Yes (1) & Yes (1) & Yes (1) & No & 6 \\
\hline Primary school & Yes (8) & Yes (3) & Yes (5) & Yes (3) & Yes (1) & 21 \\
\hline Secondary school & Yes (4) & Yes (2) & Yes (2) & Yes (1) & No & 9 \\
\hline Vocational school & Yes (1) & No & Yes (1) & No & No & 2 \\
\hline Tertiary Education & No & No & No & No & No & 0 \\
\hline
\end{tabular}

* "Yes" means, "it is present" and "No" means, "it is not present".

Further, more than five different families residing in the same dwelling unit are very common residential arrangements in the study areas as given in Table 6 below.

Table 6. Respondent's Households (HH)

\begin{tabular}{|c|c|c|c|c|c|}
\hline Household Size & Rokupr & Mambolo & Kychom & Kassiri & Yeliboya \\
\hline & $\begin{array}{c}\text { Frequency } \\
(\%)\end{array}$ & $\begin{array}{c}\text { Frequency } \\
(\%)\end{array}$ & $\begin{array}{c}\text { Frequency } \\
(\%)\end{array}$ & $\begin{array}{c}\text { Frequency } \\
(\%)\end{array}$ & $\begin{array}{c}\text { Frequency } \\
(\%)\end{array}$ \\
\hline $1-3$ & $1(0.5)$ & $0(0)$ & $2(1)$ & $0(0)$ & $1(0.5)$ \\
\hline $4-6$ & $25(12.5)$ & $30(15)$ & $35(17.5)$ & $37(18.5)$ & $33(16.5)$ \\
\hline $7-9$ & $14(7)$ & $10(5)$ & $3(1.5)$ & $3(1.5)$ & $6(3)$ \\
\hline
\end{tabular}

$* \%=$ percentage frequency

Table 7 also provides the income category of the commercially viable mangrove products in the coastal communities and range from amounts less than Le200, $000(<\$ 30)$ to that greater than Le1, 000,000 ( $>\$ 115)$ obtained weekly or per farming season in the case of rice farming. The Sierra Leone Leones-United States Dollars exchange rate is taken at, USD1 = Le8, 500. 
Table 7. Ranking income category

\begin{tabular}{|c|c|c|c|c|c|c|}
\hline & $\begin{array}{c}\text { Mangrove } \\
\text { Oyster } \\
\text { collection }\end{array}$ & $\begin{array}{c}\text { Wood } \\
\text { cutting }\end{array}$ & $\begin{array}{c}\text { Other occupations } \\
\text { related to } \\
\text { mangroves }\end{array}$ & Fishing & Farming & $\begin{array}{c}\text { Salt } \\
\text { production }\end{array}$ \\
\hline$<$ Le200,000 & 1 & 1 & 1 & 1 & 1 & 2 \\
\hline $\begin{array}{c}\text { Le201,000- } \\
\text { Le400,000 }\end{array}$ & 1 & 2 & 2 & 2 & 1 & 3 \\
\hline $\begin{array}{c}\text { Le401,000- } \\
\text { Le600,000 }\end{array}$ & 1 & 3 & 1 & 2 & 1 & 1 \\
\hline $\begin{array}{c}\text { Le601,000- } \\
\text { Le1million }\end{array}$ & 2 & 1 & 1 & 1 & 2 & 1 \\
\hline$>$ Le1million & 3 & 1 & 1 & 2 & 3 & 1 \\
\hline
\end{tabular}

$* 1=$ less common; $2=$ common; 3 = very common and important

The figures (ranks) show the commonality of the income categories for economic activities. A rank of " 3 " indicates the most common income category obtained for economic activity by the locals. It also emphasizes the importance of economic activity. The reverse is true for the rank "1". Fig. 2 also reveals the material assets of respondents for the total sample population $(\mathrm{N})$. Assets such as television, generator and bicycle were not owned by any of the respondents.

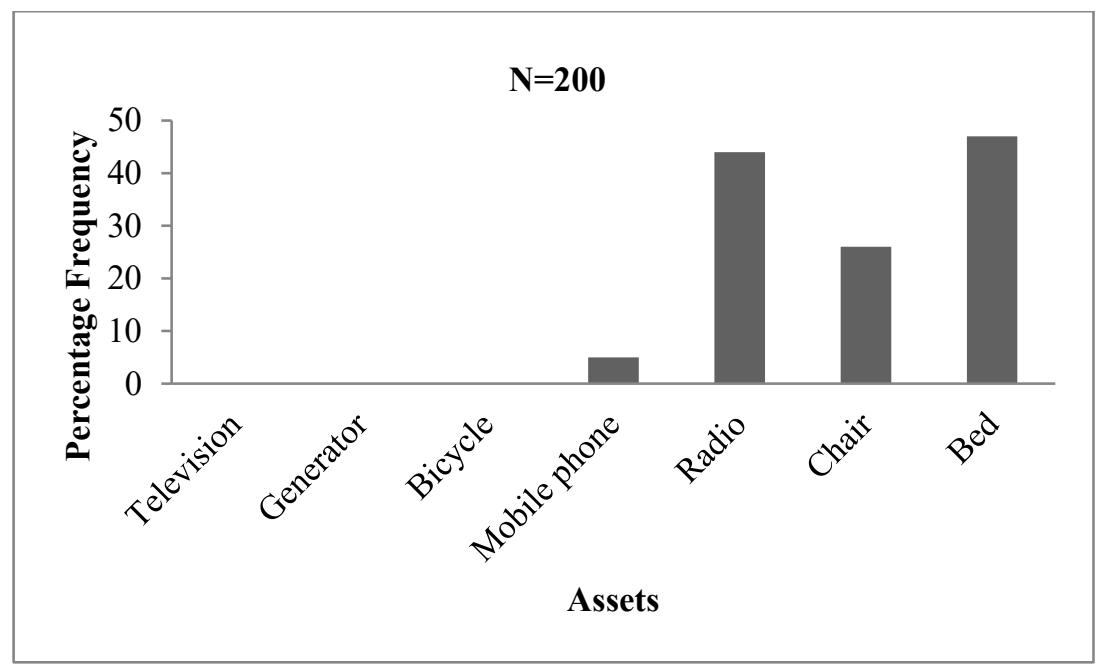

Figure 2. Total percentage frequencies of household assets

\section{Discussions}

\section{Age and Gender}

Data for this study elucidates that an average proportion $(51.5 \%)$ of the sampled respondents generally fell within a more active and productive age group. Such age group, probably with more economic and social demands in life, may be capable enough to make decisions that could influence resource use. In addition, a female to male sex ratio of 1:2.3 suggests high involvement of men in mangrove-related economic activities than the women in the study areas. The men are usually considered "bread winners" of families in this part of the world, and the quest of these for sustained livelihood could in turn have its negative impact on the Mangrove Ecosystems where it is a readily available option for livelihood in the area. [93] inferred that access to resources and knowledge about those resources are influenced by a range of factors including age and gender. However, the difference in sex of mangrove dependants is not significant at $(\mathrm{P}>0.05)$. This further suggests that mangrove resource exploitation is independent of gender. It could be that women play pivotal role in supporting men in other economic activities such as farming, fishing and salt production, aside their involvement in the sale of oyster and cockles. The involvement of both men and women in mangrove-related 
economic activities for local livelihood provide additional pressures on the ecosystem's resources in the Scarcies Estuary. [16] had indicated that the cumulative effects of men and women on mangroves through repetitive and higher harvest frequency not only affect the population dynamics of mangroves but also have the potential to undermine mangrove ecosystem sustainability. Other studies have shown that combined actions of men and women might transcend mangrove stands structural impairment to influence soil quality, forest productivity and physio-chemical properties of nutrient cycling [94-95]. It has also been revealed that persistent human iinvolvement in the mangrove forests can lead to alteration and interference with recruitment of macrofauna assemblages significant to the structure and functioning of mangrove ecosystems [96-97]. Other researchers have concluded that conflict between human needs and preferences and the conditions favored by mangroves is the fundamental driver for the loss and degradation of these ecosystems [38], and this decline continues in many regions [39-45].

\section{Living Conditions}

The study further shows the socio-economic constraints in the Scarcies Estuary, which also include the lack of basic material assets. Multiple households in a dwelling unit suggest increased population and probably less financial capacity of inhabitants to own or rent a house in the area. Such living conditions connote poor wellbeing defined by other authors as "the resources people have, such as money and other assets [98]; how people feel about their lives [99-100]; and what people are able to be and to do [101-102]. In addition, such way of life is in the context of the definition of poverty, understood as a deprivation of basic needs, low wellbeing with such outcomes as lack of basic material assets, poor health and illiteracy [103]. Studies in Sierra Leone had also shown high poverty rate in the study areas [104]. Poor living conditions and low level of western educational attainment have been shown to render the Mangrove Ecosystems vulnerable to unsustainable exploitation where there are no stringent laws governing resources use [16]. In addition, it is possible that the high financial cost attached to some material assets such as bicycle, television and generator is what is making them less preferred or unaffordable. This clearly suggests poor financial capacity by individuals in these communities. Studies have shown that material poverty of coastal communities in the absence of an alternative means of livelihood could trigger a widespread dependence on mangrove products to meet basic subsistence and income needs in the area $[16,95]$. Also, where the ecosystem cannot adequately provide food and income, locals might resolve into more destructive forms of economic activities such as the conversion for farming and salt production as dominantly practiced in the study areas. This, therefore, increases the vulnerability of the mangrove ecosystem. A related study had shown that the world's poorest people depend primarily on environmental goodsand-services for their livelihoods, which make them particularly sensitive and vulnerable to environmental changes [105]. [5] concluded that reduction in household income, lack of basic educational facilities as well as other material needs might result in communities forced into unsustainable forms of income generation where these are available. The unsustainable use of mangrove resources through ecosystems conversion, probably as a result of increasing population size and poverty is fragmenting and depleting this system on a large scale in the Scarcies Estuary. [106] concluded that the conversion of mangrove forests forces the alteration of flora, soils and biodiversity loss.

However, data also shows that $86 \%$ of the respondents are engaged in economic activities linked with the mangrove ecosystems. Such incentives for income, where they provide readily available options, may tremendously affect the ability and willingness of these communities to conserve their local mangrove forests. Studies have proven that mangroves are widely recognized as being one of the most important and valuable of coastal ecosystems [76-77]. A work done by [107] had shown that alternative livelihood opportunities are required in order to replace unsustainable practices, which could foster positive attitudes towards mangrove conservation among local communities.

Notwithstanding, some of the social and economic challenges faced by the current generation of coastal dwellers in the Scarcies Estuaries may be the long term effects of the vices of unsustainable 
exploitation and conversion of the mangrove ecosystem for farming and salt production. [61] revealed that continuous degradation and deforestation because of uncontrolled exploitation and land conversion is taking place on a large scale across West-Central Africa. Other studies further affirmed that Conversion to saltpans [49], and agriculture [51, 75, 108] are key drivers of mangrove loss in some parts of Africa. In consequence, the benefits derived from the mangrove would drastically reduce as these provide opportunities for education [47]; provide access to basic material for good life [5]; play a key role in supporting human well-being [109]. [16] also argued that as mangroves dwindle, the livelihoods and well-being of vulnerable coastal communities that directly or indirectly depend on their resources are at risk. Other researchers have concluded that continuous loss of mangroves could lead to a reduction in fish catch, property loss, and an increase in poverty levels and hence human suffering [110-111]. Economists have also predicted that excluding the income from collecting mangrove forest products would significantly raise the number of people in coastal villages in poverty [112]. In addition, well-managed mangroves could provide employment and income for coastal communities [113]; provides food and materials for trade [114]. The ecosystem services mangroves provide contribute significantly to human well-being $[4,8,9,12]$.

\section{Conclusions}

The study highlights key challenges facing the coastal communities in terms of poor health facilities, education, material assets as well as poor residential arrangements. There is a high reliance on mangrove resources for income, which suggests limited options for revenue generation in the study areas. In essence, there is pressure on the Mangrove Ecosystems and where the ecosystem cannot adequately meet basic subsistence and income needs, locals resolve into more destructive forms of economic activities such as conversion for farming and salt production. In addition, the cumulative effects of men and women engaged in mangrove-related economic activities have the potential to undermine the mangrove ecosystem's sustainability. Hence, it is increasingly evident that the conservation of mangroves in this region cannot be done without considering the varying impacts of poverty, gender roles and resource utilisation patterns. In addition, to help sustain mangroves in this area, communities need to be provided with alternative sources of livelihood and educated on the values of mangroves and regeneration techniques.

\section{Conflict of Interest}

The publication is self-sponsored and the authors declare that there is no conflict of interest.

\section{Acknowledgements}

The authors are grateful to the Institute of Marine Biology and Oceanography, University of Sierra Leone, for providing an enabling environment for the study.

\section{References}

[1] D. M. Alongi, The Energetics of Mangrove Forests. Transport, 36 (2009) 228.

[2] D. C. Donato et al., Mangroves among the most carbon-rich forests in the tropics. Nat. Geosci. 4 (2011) 293-297.

[3] C. Giri et al., Status and distribution of mangrove forests of the world using Earth Observation Satellite Data. Global Ecology and Biogeography. 20 (2011) 154-159.

[4] K. S. Sarker, Spatial and temporal patterns of mangrove abundance, diversity and functions in the Sundarbans, Ph.D. dissertation, Institute of Biodiversity, Animal Health and Comparative Medicine College of Medical, Veterinary and Life Sciences, Univ., of Glasgow, Glasgow, 2017. 
[5] UNEP (United Nations Environment Program). "The Importance of Mangroves to People": A Call to Action, 2014. Networks [Online]. Available: https://www.unewcmc.org/.../theimportance-of-mangroves-to-people--a-call-to-acti.

[6] M. R. Bomfim et al., Morphology, Physical and Chemical Characteristics of mangrove soil under riverine and marine influence: A Case Study on Subaé River Basin, Bahia, Brazil, 2017.

[7] G. N. Ajonina, Inventory and modelling mangrove forest stand dynamics following different levels of wood exploitation pressures in the Douala-Edea Atlantic coast of Cameroon, Central Africa, Ph.D. dissertation, Univ., of Freiburg, Germany, 2008.

[8] M.J. Osland, et al., Climatic controls on the global distribution, abundance, and species richness of mangrove forests. Ecological Monographs. 87(2) (2017) 341-359.

[9] MA (Millennium Ecosystem Assessment), Ecosystems and human well-being: Current state and trends. The Millennium Ecosystem Assessment series. xxi,. (IslandPress), 2005, pp.917.Networks[Online].Available:http://www.indianocean.org/bioinformatics/mangrove/ma ngcd/indo/pl.htm.

[10] S.N. Dudani et al., Heavy Metal Accumulation in the Mangrove Ecosystem of South Gujarat Coast, India. 17 (2017) 755-766.

[11] I. Nagelkerken et al., Importance of mangroves, seagrass beds and the shallow coral reef as a nursery for important coral reef fishes, using a visual census technique. Estuarine, Coastal and Shelf Science. 51 (200) 31-44.

[12] M. Dorenbosch et al., The relationship of reef fish densities to the proximity of mangrove and seagrass nurseries. Estuarine Coastal and Shelf Science. 60 (2004) 37-48.

[13] P.J. Mumby et al., Mangroves enhance the biomass of coral reef fish communities in the Caribbean Nature. 427 (2004) 533-536.

[14] M. Carrasquilla-Henao, F. Juanes, Mangroves enhance local fisheries catches: a global metaanalysis. Fish and Fisheries. 18(1) (2017) 79-93.

[15] F.J. Manson et al., An evaluation of the evidence for linkages between mangroves and fisheries: a synthesis of the literature and identification of research directions. Oceanography and Marine Biology: An Annual Review. 43 (2005) 485-515.

[16] Z. Njisuh et al., The effects of different gender harvesting Practices on mangrove ecology and conservation in Cameroon. 7(2) (2011) 108-121.

[17] C. Gordon, Principles for a Code of Conduct for the Sustainable Management of Mangrove Ecosystems. Centre for African Wetlands, 2005. Networks [Online]. Available:.http://mit.biology.au.dk/cenTER/MCB_Fil es/Ramsar/2005_Ramsar_Arusha_V2.

[18] D.M. Alongi, Carbon sequestration in mangrove forests, a review. Carbon Management. 3 (2012) 313-322.

[19] D.M. Alongi, The Impact of Climate Change on Mangrove Forests. Current Climate Change Reports. 1 (2015) 30-39.

[20] E.L. Gilman et al., Threats to mangroves from climate change and adaptation options: A review. Aquat. Bot. 89 (2008) 237-250.

[21] K.W. Krauss et al., Surface Elevation Change and Susceptibility of Different Mangrove Zones to Sea-Level Rise on Pacific High Islands of Micronesia. Ecosystems. 13 (2010) 129-143.

[22] Abu Dhabi Global Environmental Data Initiative, Blue Carbon in Abu Dhabi-Protecting our Coastal Heritage: A report from the Abu Dhabi Blue Carbon Demonstration Project, 2013. 
[23] E.B. Barbier et al., Coastal ecosystem-based management with nonlinear ecological functions and values. Science. 319 (2998) 321-323.

[24] E.W. Koch et al., Non-linearity in ecosystem services: temporal and spatial variability in coastal protection. Frontiers in Ecology and the Environment. 7 (2009) 29-37.

[25] A. McIvor et al., The response of mangrove soil surface elevation to sea level rise. Natural Coastal Protection Series: Report 3. Cambridge Coastal Research Unit Working Paper 42. (2013) pp. 59.

[26] D.M. Alongi et al., The influence of fish cage culture on pelagic carbon flow and water chemistry in tidally dominated mangrove estuaries of Peninsular Malaysia. Marine Environmental Research. 55 (2003) 313-333.

[27] P. Harbison, Mangrove muds - a sink and a source for trace metals. Marine Pollution Bulletin. 17 (1986) 246-250.

[28] J.H. Primavera, Mangroves, fishponds and the quest for sustainability. Science. 310 (2005) 5759.

[29] J.H. Primavera et al., Mangroves and shrimp pond culture effluents in Aklan, Panay Is., Central Philippines. Bulletin of Marine Sciences. 80 (2007) 795-804.

[30] J. Brohman, New directions in tourism for third world development. Annals of Tourism Research. 23 (1996) 48-70.

[31] P.R. Bacon, G.P. Alleng, The management of insular Caribbean mangroves in relation to site location and community type. The Ecology of Mangrove and Related Ecosystems. 80 (1992) 235-241.

[32] C.D Field, Charter for Mangroves, in: A. Yáñez-Arancibiay, A.L. Lara-Domínguez (Eds.), Ecosistemas de Manglar en América Tropical. Instituto de Ecología. A.C. México, UICN/ORMA, Costa Rica, 1999.

[33] G. K. James et al., Social valuation of mangroves in the Niger Delta region of Nigeria. Int. J. Biodivers. Sci. Ecosyst. Serv. Manag. 9 (2013) 311-323.

[34] H. Van Lavieren et al., Securing the future of mangroves. A Policy Brief. UNU-INWEH, UNESCOMAB with ISME, ITTO, FAO, UNEP-WCMC and TNC, 2012, pp. 53.

[35] O. Steven et al., Exploring mangrove social-ecological system dynamics in South-east Asia: linking livelihoods, vulnerability and ecosystem services in Vietnam Sustainability Research Institute, Paper No.56, 2014.

[36] B.B. Walters et al., Ethnobiology, socio-economics and management of mangrove forests: a review. Aquatic Botany. 89 (2008) 220-236.

[37] M.G. Samoilys et al., Situation analysis for Mangroves for the Future: Understanding the resilience of coastal systems, 2013.

[38] UNEP (United Nations Environment Program), Mangroves of Western and Central Africa, 2007, p. 88.

[39] B.A Polidoro et al., The Loss of Species: Mangrove Extinction Risk and Geographic Areas of Global Concern. PLoS ONE. 5 (2010) 1-10.

[40] L.M. Brander et al., Ecosystem service values for mangroves in Southeast Asia: A metaanalysis and value transfer application. Ecosyst. Serv. 1 (2012) 62-69.

[41] B. Daru et al., A Global Trend towards the Loss of Evolutionarily Unique Species in Mangrove Ecosystems.PLoS One, 2013. 
[42] R. DasGupta, R. Shaw, Cumulative Impacts of Human Interventions and Climate Change on Mangrove Ecosystems of South and Southeast Asia: An Overview, 2013, pp. 1-15.

[43] C.F. Chen et al., Multi-Decadal Mangrove Forest Change Detection and Prediction in Honduras, Central America, with Landsat Imagery and a Markov Chain Model. Remote Sens. 5 (2013) 6408-6426.

[44] W. Cormforth et al., Advanced Land Observing Satellite Phased Array Type L-Band SAR (ALOS PALSAR) to Inform the Conservation of Mangroves: Sundarbans as a Case Study. Remote Sens. 5 (2013) 224-237.

[45] A.J.R. Rideout et al., Making predictions of mangrove deforestation: a comparison of two methods in Kenya. Glob. Chang. Biol. 19 (2013) 3493-3501.

[46] S. Martinuzzi et al., Conversion and recovery of Puerto Rican mangroves: 200 years of change. For. Ecol. Manage. 257 (2009) 75-84.

[47] M. Spalding et al., World Atlas of Mangroves. ITTO, ISME, FAO, UNEP-WCMC, UNESCOMAB and UNU-INWEH. Earthscan Publishers Ltd. London, 2010.

[48] N.Z. Feka, G.N. Ajonina, Drivers causing decline of mangrove in West-Central Africa: a review. Int. J. Biodivers. Sci. Ecosyst. Serv. Manag. 7 (2011) 217-230.

[49] Nfotabong-Atheull et al., Assessing forest products usage and local residents' perception of environmental changes in peri-urban and rural mangroves of Cameroon, Central Africa. J. Ethnobiol. Ethnomed. 7 (2011) 41.

[50] A.F. Rahman et al., Detecting large scale conversion of mangroves to aquaculture with change point and mixed-pixel analyses of high-fidelity MODIS data. Remote Sens. Environ. 130 (2013) 96-107.

[51] E.L. Webb et al., Deforestation in the Ayeyarwady Delta and the Conservation implications of an internationally-engaged Myanmar. Glob. Environ. Chang. 24 (2013) 321-333.

[52] E.A. Cherrington et al., Technical Report: Identifying of Threatened and Resilient Mangroves in Belize Barrier Reef System. Development, 2010, pp. 1-33.

[53] F. Dahdouh-Guebas et al., Human hydrographical changes interact with propagule predation behaviour in Sri Lankan mangrove forests. J. Exp. Mar. Bio. Ecol. 399 (2011) 188-200

[54] K.B. Kirui et al., Mapping of mangrove forest land cover change along the Kenya coastline using Landsat imagery. Ocean Coast. Manag. 83 (2013) 19-24.

[55] A. Satyanarayana et al., Long-term mangrove forest development in Sri Lanka: early predictions evaluated against outcomes using VHR remote sensing and VHR ground-truth data. Mar. Ecol. Prog. Ser. 443 (2011) 51-63.

[56] S. Sandilyan, K. Kathresan, Plastics - a formidable threat to unique biodiversity of Pichavaram mangroves. Curr. Sci. 103 (2012) 1262-1263.

[57] S.D.A. Smith, Marine debris: a proximate threat to marine Sustainability in Bootless Bay, Papua New Guinea. Mar. Pollut. Bull. 64 (2012) 1880-1883.

[58] S. Pegg, N. Zabbey, Oil and water: The Bodo spills and the destruction of traditional livelihood structures in the Niger Delta. Community Dev. J. 48 (2013) 391-405.

[59] N. Din et al., Logging activities in mangrove forests: a case study of Douala Cameroon. 2 (2008) $22-30$.

[60] D. Di Nitto et al., Mangroves facing climate change: landward migration potential in response to projected scenarios of sea level rise. Biogeosciences. 11 (2014) 857-871. 
[61] T.E. Fatoyinbo et al., Landscape-scale extent, height, biomass, and carbon estimation of Mozambique's mangrove, forests with Landsat ETM+ and Shuttle Radar Topography Mission elevation data. Geophys. Res. G Biogeosciences, 2008, pp. 113.

[62] C. Giri, J. Muhlhausen, Mangrove forest distributions and dynamics in Madagascar (19752005). Sensors. 8 (2008) 154-159.

[63] R. Chevallier, Balancing Development and Coastal Conservation: Mangroves in Mozambique, 2013. Networks [Online]. Available: http://www.isn.ethz.ch/DigitalLibrary/Publications/ Detail/?lng=en\&id=174162.

[64] E.T. Ndomahina, An Assessment of the State of the Marine Biodiversity in Sierra Leone. Consultancy Report, Sierra Leone Maritime Administration (SLMA), 2002, pp. 98.

[65] I. Turay, S. Kamara, Desk Review of proposed Marine Protected Areas in Sierra Leone. (Ministry of Fisheries and Marine Resources, Freetown), 2010.

[66] Government of Sierra Leone, Fifth National Biodiversity and Strategic Action Plan for Sierra Leone, Freetown. Department of Environment, Environment Protection Agency-Sierra Leone), 2015.

[67] A.R. Longhurst, Bionomics of the Fisheries Resources of the Eastern. Fish Publ. Col. Office London. 20 (1962) pp 660.

[68] A.A. Aleem, D.E.B Chaytor, Further observations on Marine Mollusca of Sierra Leone. West Africa. Bull. IFAN. 43(3) (1980) 571-585.

[69] K.M.B Garnett, S.A. Mansaray, Strategies for Conservation and Sustainable Management of Mangrove Forest in Sierra Leone, 2007, pp. 6-7.

[70] P. W. Chong, Proposed management and integrated utilization of mangrove resources in Sierra Leone. FAO / Ministry of Agriculture, Natural Resources and Forestry. FO: DP / SIL / 84 /003, 1987.

[71] GoSL (Government of Sierra Leone), A Framework for Integrated Coastal Zone Management. Freetown: Department of Environment, Environment Protection Agency-Sierra Leone, 2015.

[72] COMARAF, Productivity of Estuaries and Mangroves of West Africa. COMARAF PROGRAM. Joint Research Workshop. Multidisciplinary Study of the Bunce River, Sierra Leone. Technical Report, 1990, pp. 20.

[73] R.G. Johnson, R.G. Johnson, The natural and extent of human impacts on the Estuaries and Bays of Sierra Leone. UNESCO Regional Seminar ROSTA (5 - 9 April, 1993), 1995, pp. 7889.

[74] L. Blinker, Country Environmental Profile. Sierra Leone. CONSORTIUM PARSONS BRINCKERHOFF (European Commission; Government of Sierra Leone. EU/GoSL, 2006.

[75] FAO (Food and Agricultural Organization), Global Forest ResourcesAssessment.Thematic Study onMangroves of Sierra Leone. Country Profile, 2005.

[76] A.J. Lopez, The conservation status of mangroves and their contribution to artisanal fisheries in the Eastern Tropical Pacific. Ph.D. dissertation, Univ. of York, 2016.

[77] C.A. Duncan, Mangrove forest ecosystem services: Biodiversity drivers, rehabilitation and resilience to climate change. Doctoral thesis, Univ., College, London, 2017.

[78] IMBO (Institute of Marine Biology and Oceanography), Ecological, Hydrological and Socioeconomic Baseline survey in four (4) proposed Marine Protected Areas of the Sierra Leone Coast, 2015.

[79] J.A. Jimenez et al., Tree mortality in mangrove forests. Biotropica. 17(3) (1985) 177-185. 
[80] R.E. Sherman et al., Small scale disturbance and regeneration dynamics in a neotropical mangrove forest. J. Ecol. 88 (2000) 165-178.

[81] B. Worm et al., Impacts of biodiversity loss on ocean ecosystem services. Science. 314 (2006) 787-790.

[82] M. Agyen-Sampong, K. Prakah-Asante, S.N. Fomba, Rice improvement in the Mangrove swamps of West Africa. (West Africa Rice Development Association (WARDA) Regional Mangrove Swamp Rice Research Station, Freetown, Sierra Leone), 1987.

[83] P.C. Coutin, The effect of long-term exploitation of Tropical Demersal Fish Stock. Ph.D, dissertation, Coventry Polytechnic, United Kingdom, 1989, pp. 243.

[84] G.W. Ssentengo, M. Ansa-Emmin, Marine Fishery Resources of Sierra Leone: A Review of Exploited Stocks. FAO CECAF/ECAF Ser. 86/34, 1986, pp. 67.

[85] R. Chambers, Rural Appraisal: Rapid, Relaxed and Participatory: IDS Discussion Paper 311, 1992.

[86] P. Townsley, Rapid rural appraisal, participatory rural appraisal and aquaculture: FAO, Rome (Italy). Fisheries Dept./FAO Fisheries Technical Paper, 1996, Issue 358, 1996.

[87] J.A. McCracken, Participatory Rapid Appraisal in Gujarat: A trial model for the Aga Khan Rural Support Programme (India), ITED, London, 1998.

[88] L. Luck et al., Components of observable behavior that indicates potential for patient violence in emergency departments. Journal of Advanced Nursing. 59 (2007) 11-19.

[89] Y. Kassam, M. Kamel, Participatory Research: An emerging alternative methodology in Social Science Research, Society for participatory research in Asia, 1982.

[90] Action Aid, Participatory Rural Appraisal in identifying major illness, Health care Providers and Costs. Action Aid, Bangalore, 1991.

[91] G. Ryan, H. R. Barnard, Techniques to Identify Themes in Qualitative Data.Department of Anthropology 1350 Turlington Hall University of Florida Gaineville, 2000.

[92] R.K. Yin, Case study research: Design and methods (3rd ed.). Thousand Oaks, CA: Sage, 2003.

[93] S.V. Siar, Knowledge, Gender, and Resources in Small-Scale Fishing: The Case of Honda Bay, Palawan, Philippines. Environ. Manage. 31 (2003) 569-580.

[94] J.C. Ellison, Impact of sediment burial on mangroves. Mar Poll Bull. 37 (1998) 420-426.

[95] P.M. Ross, Macrofaunal loss and microhabitat destruction: the impact of trampling in a temperate mangrove forest, NSW Australia. Wetlands Ecol Manage. 14(2) (2006) 167-182.

[96] S. Cannicci et al., Faunal impact on vegetation structure and ecosystem function in mangrove forests: a review. Aquat Bot. 89 (2008) 186-200.

[97] A.Rajkaran, J.B. Adams, The implications of harvesting on the population structure and sediment characteristics of the mangroves at Magazana Estuary, Eastern Cape, South Africa. Wetlands Ecol Manag. 18(1) (2009) 79-89.

[98] R. M. Solow, Sustainability: An Economist's Perspective. The Eighteen J. Seward Johnson Lecture to the Marine Policy Center, Woods Hole Oceanographic Insitution. In Economics of the Environment, Norton, New York, 1991, pp. 179-187.

[99] E. Diener, Subjective well-being. The science of happiness and a proposal for a national Index. In the American Psychologist. 55 (2000) 34-43.

[100] B. Frey, A. Stutzer, Beyond Outcomes: Measuring Procedual Utility. In Oxford Economic Papers. 57(1) (2005) 90-111. 
[101] A.Sen, Commodities and Capabilities, Oxford University Press, Oxford, 1985. Networks [Online]. Available: http//:www.sciepub.com/reference/7155.

[102] A. Sen, Inequality Re-examined. Clarendon Press, Oxford, 1992. Networks [Online]. Available: https://books.google.com.sl/books?hl=en\&lr=\&id=D6_eCtTK6-oC\&oi=fnd\&pg= PA1\&dq=Sen, + A. $+(1992) .+$ Inequality + Reexamined. + Clarendon + Press, + Oxford.\&ots $=$ GMY NrIAIQO\&sig.

[103] UN (United Nations), Human Rights and Poverty Reduction. A conceptual framework. United Nations Office of the High Commissioner for Human Rights. United Nations, New York and Geneva, 2004.

[104] GoSL (Government of Sierra Leone). Census poverty Analysis: Statistics Sierra Leone, 2004.

[105] WRI (World Resources), The Wealth of the Poor - Managing Ecosystems to Fight Poverty. World Resources Institute in collaboration with the United Nations Development Programme, the United Nations Environment Programme and The World Bank. World Resources Institute, Washington, DC, 2005.

[106] L.P Koh, D.S. Wilcove, Is oil palm agriculture really destroying tropical biodiversity? Conserv Lett. 1(2) (2008) 60-64.

[107] R. Badola et al., Attitudes of local communities towards Conservation of mangrove forests: A case study from the east coast of India. Estuary. Coast. Shelf Sci. 96 (2012) 188-196.

[108] Valiela et al., Mangrove Forests: One of the World's Threatened Major Tropical Environments. Bioscience. 51 (2001) 807.

[109] D. Russi et al., The Economics of Ecosystems and Biodiversity for Water and Wetlands. Vasa 84, 2013.

[110] IPCC (Intergovernmental Panel for Climate Change), Special report on the regional impacts of climate changes, an assessment of vulnerability. Univ., of Cambridge, United Kingdom, 2001.

[111] IPCC (Intergovernmental Panel for Climate Change), Mitigation of climate change, working group III fourth assessment report, intergovernmental panel on climate change, 2007.

[112] Sarntisart, S. Sathirathai, Shrimp farming mangrove loss in Thailand, 2004, pp. 96-113.

[113] Magalhães et al., The role of women in themangrove crab (Ucides cordatus, Ocypodidae) production process in North Brazil (Amazon region, Pará). Ecol. Econ. 61 (2007) 559-565.

[114] C. Govindasamy, R. Kannan, Pharmacognosy of mangrove plants in the system of unani medicine. Asian Pacific J. Trop. Dis. 2 (2012) 38-41. 